\title{
Geodynamics of the Ural Foredeep and Geomechanical Modeling of the Origin of Hydrocarbon Accumulations
}

\author{
N. B. Kuznetsov ${ }^{a, b}$, V. Yu. Kerimov ${ }^{b, c, *}$, A. V. Osipov ${ }^{b}$, A. V. Bondarev ${ }^{b}$, and A. S. Monakova ${ }^{b}$ \\ ${ }^{a}$ Geological Institute of the Russian Academy of Sciences, Moscow, 109017 Russia \\ ${ }^{b}$ Gubkin Russian State University of Oil and Gas, Moscow, 119991 Russia \\ ${ }^{c}$ Ordzhonikidze Russian State Geological Prospecting University, Moscow, 117997 Russia \\ *e-mail:vagif.kerimov@mail.ru \\ Received November 26, 2017
}

\begin{abstract}
We present tectonic implications for hydrocarbon accumulations in the Ural-Novaya Zemlya Foredeep. Its eastern flank is rich in economical oil and gas deposits mostly localized within the fold-andthrust belt that was constructed as a result of continent-continent collision during the Ural Paleoocean closure. On the basis of striking correlation between oil and gas accumulation and fold-and-thrust tectonics we performed geomechanical and petroleum systems modelling that allowed us to propose a new geodynamical model for hydrocarbon accumulations in both fold-upthrust and subthrust structural levels of the Ural-Novaya Zemlya Foredeep.
\end{abstract}

Keywords: upthrust fault structures, subthrust zones, geomechanical modeling, Ural Frontal Folds, Ural foredeep, fore-Ural/fore-Novaya Zemlya belt of hydrocarbon accumulations, hydrocarbons

DOI: $10.1134 / \mathrm{S} 0016852118030044$

\section{INTRODUCTION}

The epi-Paleozoic Ural-Mongolian Fold Belt is constrained to the central part of the modern structure of Eurasia. Geographically and structurally, the belt separates the ancient East European, Siberian, Tarim, and North China platforms of the single Eurasian continent (Fig. 1). Belts as individualized megaregional structural units were first recognized by M.V. Muratov [19]. Currently, they are referred to as orogenic or fold belts, e.g., the Central Asian Orogenic Belt $[1,42]$. The westernmost element of the Ural-Mongolian Fold Belt is the Ural-Novaya Zemlya fold system [29], which extends nearly meridionally for more than $4000 \mathrm{~km}$ from the northern tip of the Novaya Zemlya archipelago in the north to the Caspian Depression in the south.

The Ural-Novaya Zemlya Fold Belt is structurally and paragenetically associated with a negative structure that extends along this fold belt throughout its entire length and is referred to as the Ural-Pai KhoiNovaya Zemlya Foredeep.

Parts of the Ural-Novaya Zemlya Fold Belt closest to the Ural-Pai Khoi-Novaya Zemlya Foredeep are characterized by fold and thrust structure, with the pitches of the axial planes of folds and upthrust fault planes predominantly directed away from the fold belt toward regions with platform-style structure [8, 2427, 36]. The Ural-Pai Khoi-Novaya Zemlya Foredeep is highly promising as a structure hosting oil and gas accumulations. On this basis, this megastructure is distinguished in terms of hydrocarbon potential and geology as the Ural-Novaya Zemlya Forebelt of Oil and Gas Accumulations [3]. The hydrocarbon potential of the axial parts of this belt (closer to areas of platform-style structure) is well explored [9, 10, 24, 45], whereas the potential of parts of the deep closer to the epi-Paleozoic Ural Fold and Thrust Belt is largely uncertain. These parts of the deep host large hydrocarbon fields, such as the Vuktylskoe gas-condensate field in the Northern Ural part of the deep and the Saratov, Isimovo, Berkut, and other fields in the Southern Ural part.

With regard to geological zoning and hydrocarbon potential, relicts of the Ural-Novaya Zemlya Fold Belt are referred to as the Ural-Novaya Zemlya Forebelt of Oil and Gas Accumulations (Fig. 2). V.P. Gavrilov [3] was the first to distinguish this belt of hydrocarbon accumulations, as well as belts of similar genesis and paragenetic relationships with orogens produced by subduction-obduction and collision processes.

The Ural-Novaya Zemlya Forebelt of Oil and Gas Accumulations extends for approximately $4000 \mathrm{~km}$ (Fig. 2) along the southeastern and eastern peripheries of the East European Platform and, north of the segment of the Pechora suture adjacent to the Urals (Fig. 1), along the eastern periphery of the young (post-Timanian) Timan-Pechora-Barents Sea Platform. The belt is subdivided into four areas of oil and gas accumulations: the Arctic, Pechora, Eastern 


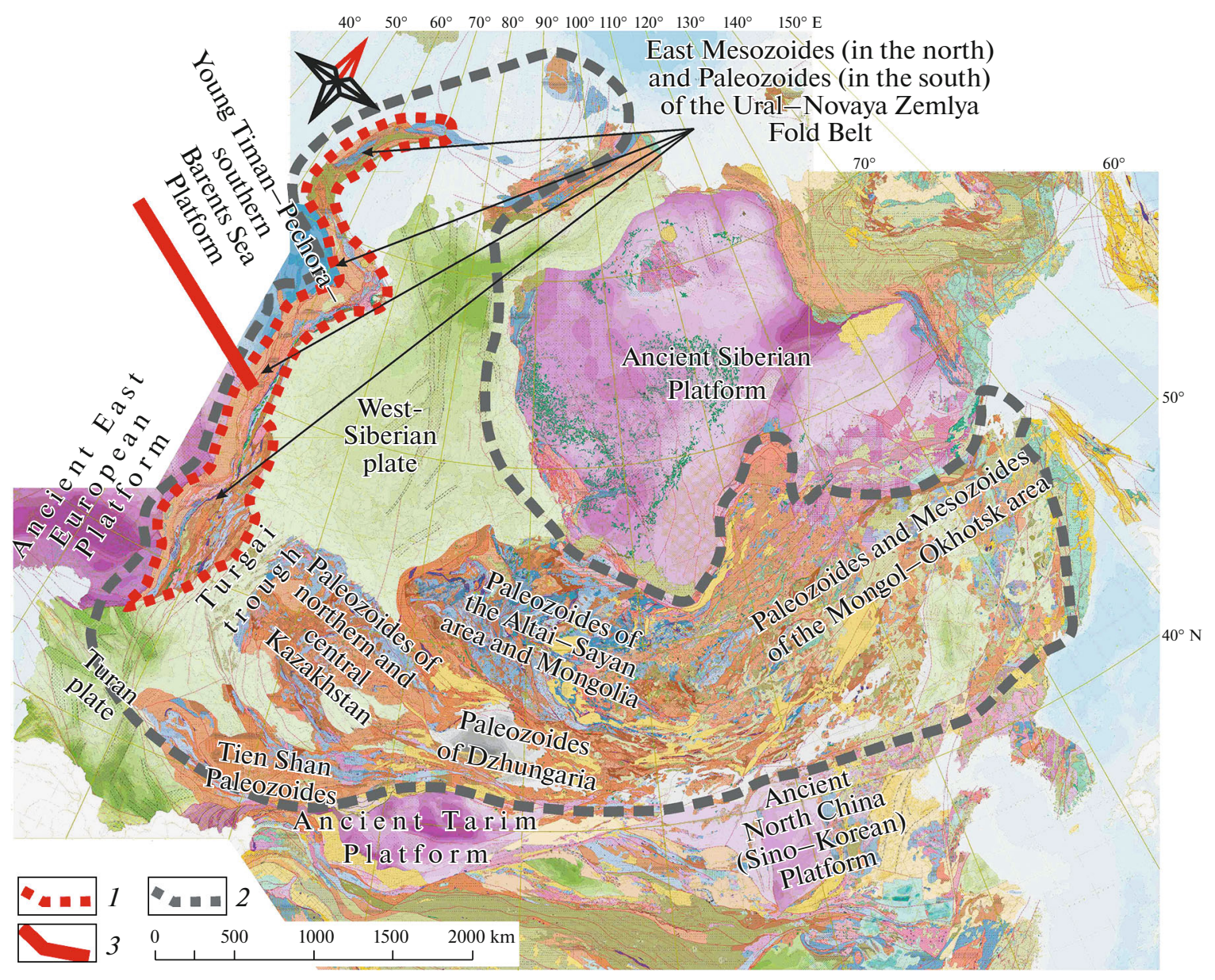

Fig. 1. Ural-Mongolian (Central Asian) Orogenic Belt and its surrounding structures (compiled with data from [46]). (1) Outer contour of Ural-Novaya Zemlya Fold Belt; (2) outer contour of Ural-Mongolian (Central Asian) Orogenic belt; (3) Pechora suture.

Volga-Ural, and Northern Caspian. These parts of the Ural-Novaya Zemlya Forebelt of Oil and Gas Accumulations host oil and gas fields that are very nonuniformly distributed over the area: areas with scattered small hydrocarbon pools are combined with areas with anomalously high hydrocarbon reserves: centers of hydrocarbon accumulation. The latter areas host uniquely large hydrocarbon fields.

Structurally, this type of hydrocarbon accumulation belts pertains to linear troughs (foredeeps). They are elongate parallel to areas of platform-style structure and to orogenic fold and thrust systems. In cross section, the deeps are typically asymmetric in terms of structure. Their slopes (flanks) adjacent (structurally and spatially related) to platform margins are characterized by relatively low thicknesses of sedimentary filling of troughs and by a mostly platform character of the structure and composition of these sedimentary sequences. In contrast, the slopes of deeps near fold and thrust edifices demonstrate increased thicknesses of sediments filling the troughs, much more complete sedimentary sequences than in the opposite flanks, and fewer hia- tuses and stratigraphic unconformities. Most importantly, the latter flanks of troughs are characterized by widespread fold and thrust structures, the vergence of which is directed from the fold and thrust edifices toward areas with platform-style structure.

In terms of geological formations and structure, the Ural-Novaya Zemlya Forebelt of Oil and Gas Accumulations corresponds to the Ural-Pai Khoi-Novaya Zemlya Foredeep. This megaregional structure initially evolved as a single foredeep but was later divided into segments by a number of transverse and diagonal rises (in order from south to north, these are the Karatau Jut, Polyudov Mountain-Ridge rise, Pechora Tectonic Ridge rise, Sobski Transverse Rise, and a rise on the north part of the Pechora Sea) and a series of depressions in between. From south to north, these are: the Bel'skaya, Yuryuzan-Sylva, Upper Pechora (Verkhne-pechorskaya), Greater Synya (Bol'shesyninskaya; including its Kos'yu-Rogovskii part), Korotaikha, and Pred-Novozemel'skii (West Novaya Zemlya) depressions (Fig. 2). 


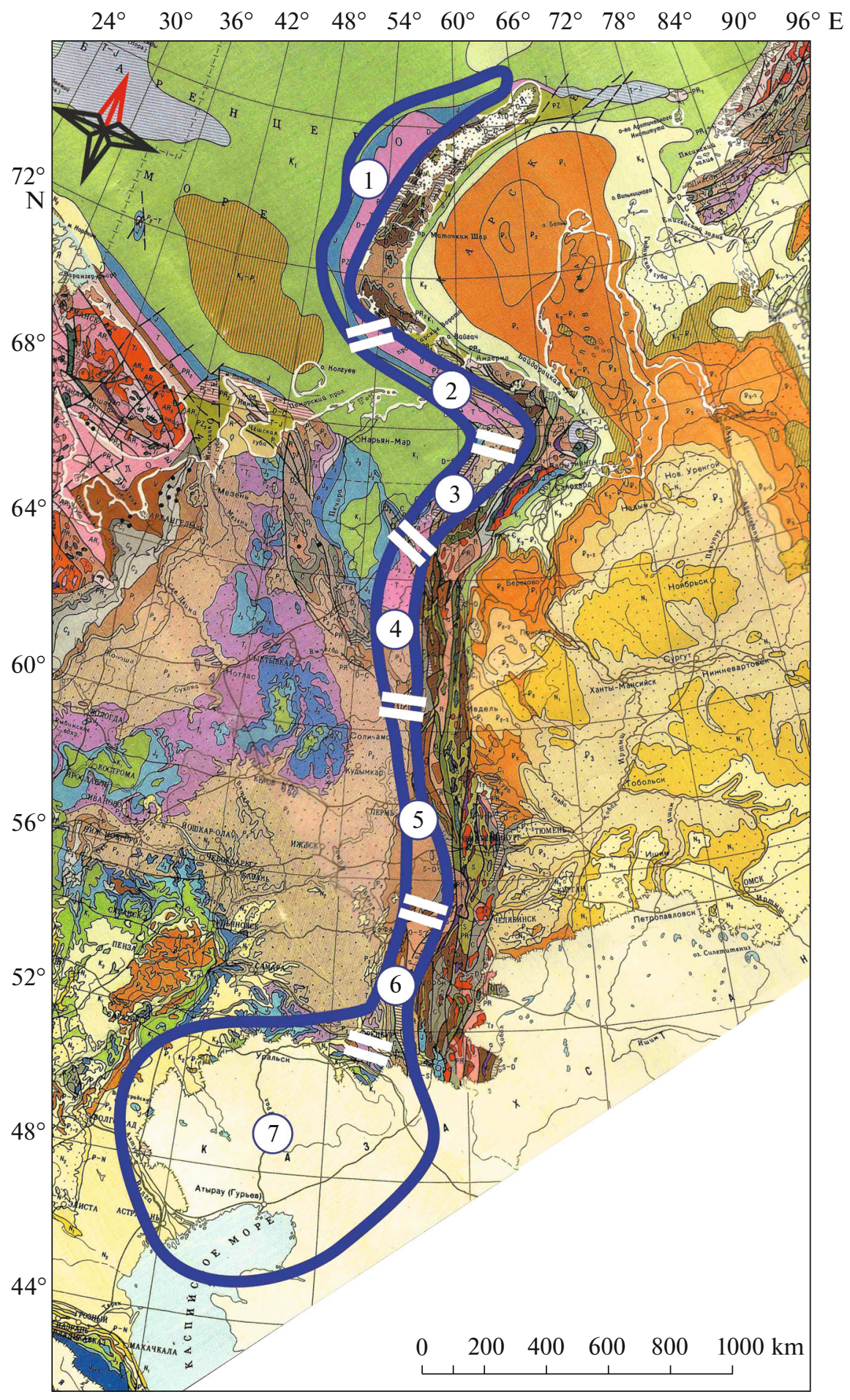

Fig. 2. Ural-Novaya Zemlya Forebelt of Oil and Gas Accumulations and schematic map of its longitudinal segments (compiled with data from [32]). Zones and depressions (circled numerals): (1) Novaya Zemlya Fold Belt. Depressions: (2) Korotaikha, (3) Greater Synya (including its northern Kos'yu-Rogovaya part), (4) Upper Pechora, (5) Yuryuzan-Sylva, (6) Bel'skaya, (7) Caspian.

We used the term upthrust in reference to a folded crustal section that corresponded to a hanging wall of detachment whereas the term subthrust corresponded to a foot wall of detachment.
This paper presents the results of our geomechanical modeling (with the Dynel program package [49]), which made it possible to reproduce the Paleozoic structural evolution of the Southern Ural segment of 
the Ural-Pai Khoi-Novaya Zemlya Foredeep and phases of the origin of the folded-upthrust fault structural parageneses (upthrust fault structures) and subthrust structures (structural features overlain by overthrusts) in the Ural Frontal Fold Zone in the eastern wall of the trough.

\section{METHODS}

The main tool employed in this research was geomechanical and numerical spatiotemporal basin simulations, which gave an insight into the conditions under which hydrocarbon accumulations were produced in the overthrust zones.

To reproduce the overthrusting processes in which the origin and evolution of the Frontal Fold Zone of the Urals were involved, we applied geomechanical computer simulations with the Dynel (Schlumberger, Texas, United States) program package [49]. This software allows a researcher to simulate a series of geomechanical paleoreconstructions (profiles). The model of the geological environment is subdivided into isotropic triangular unit cells of unspecified size for which the physical properties of rocks and interaction between them are specified. Geomechanical modeling makes it possible to estimate spatiotemporal variations in the architecture of sedimentary basins produced in various geological environments (compressional or extensional). This, in turn, enables the researcher to analyze the temporal evolution of selected structures and faults, which is of particular importance for thrust and fold areas. Analysis of the simulated geomechanical reconstructions thus provides the researcher with the principal ability to understand the evolution of active fault segments, gain insights into the pathways of hydrocarbon fluids along faults as feeder zones, and to predict potential economic hydrocarbon traps [12, 47]. Furthermore, balancing and reproduction of sedimentary sequences via geomechanical simulations makes it possible to test seismic interpretations and estimate the thicknesses of eroded sediments and shortening (extension) of sedimentary sequences during faulting and folding.

We applied the PetroMod (Schlumberger) program package to numerically simulate the generationaccumulation properties of petroleum systems via basin modeling in order to reproduce the temperature and pressure evolution with time, identify hydrocarbon generation regions (hydrocarbon kitchens) and their evolution, estimate the hydrocarbon charging parameters, and understand how oil and gas accumulations were produced in the Ural Foredeep [50]. By petroleum system we mean a naturally occurring system of a generation region/regions and all hydrocarbons genetically related to it/them. The system thus involves all elements and features required to produce hydrocarbon accumulations in a sedimentary basin: source rocks, reservoir rocks, seals, overlying rocks, and all hydrocarbon generation, migration, accumula- tion, and trap origin processes [43]. In modeling petroleum systems, the input data are of crucial importance. The volume and quality of information govern the accuracy of the models and uncertainties in the conclusions. The input dataset for modeling petroleum systems is specified by the software requirements and quantity and quality of the geological, geophysi$\mathrm{cal}$, and geochemical exploration data on the area. The major data blocks are as follows:

geometrical parameters of the basin (structuraltectonic background);

lithologies and facies of sedimentary complexes;

geochemical characteristics of source rocks;

current information on major geological events (episodes of sedimentation, hiatuses, and erosion);

boundary conditions (heat flow, paleobathymetry, and temperature at the bottom of the basin).

This simulation technology makes it possible to synthesize data acquired by geological exploration operations of different scale and utilize them as the basis for a dynamic model of the origin and evolution of petroleum systems and to assess the gas and oil potential of the area.

\section{GEOMECHANICAL MODELING}

The geomechanical modeling of the structural evolution of the Ural Frontal Fold Zone (Fig. 3) allowed us to identify the evolutionary stages of the faults and rank them. The evolutionary stages were correlated with the major episodes of the tectonic and geodynamic evolution of the Urals in the Paleozoic. Modeling results indicate that the displacement amplitudes of faults of different rank are much greater than earlier inferred from seismic profiles [23]. For example, we have proven that displacements of second-order faults exceed $66-75 \mathrm{~m}$ and sometimes reach $550 \mathrm{~m}$ or more.

The Ural Frontal Fold Zone belongs to the southern flank of the Western Ural Megazone. However, the formations of the Upper Paleozoic stratified complexes in the Frontal Fold Zone are of the same age as those in the southern part of the Ural Foredeep. Data from regional surveying, seismic operations, and specialized studies in this area $[27,28,40]$ indicate that the Ural Frontal Fold Zone is made up of Ordovician (perhaps, Ordovician-Silurian), Devonian, Carboniferous, and Lower Permian stratified sedimentary units.

Starting in the mid-Ordovician through the Middle Devonian, terrigenous and terrigenous-carbonate sedimentation in the area was associated with the development of normal faults, whose fault planes dip westward (Fig. 3, profiles 1 and 3). We believe that these normal faults formed and then evolved in association with extension processes in the Ural margin of the East European Platform at that time.

At the Devonian-Carboniferous boundary, the territory was affected by thrusting, including reverse 
thrusting, with these thrusts inheriting their fault planes from Ordovician-Devonian normal faults (Fig. 3, profiles 3 and 4). Many researchers have demonstrated that compression began in the Southern Urals in the Late Devonian (in the Famennian), and graywacke (Zilair Group) units of terrigenous material (brought from the eastern Urals) then started to accumulate $[6,7,27,29]$.

We believe that the onset of reverse faulting with western vergence in the Ural Frontal Fold Zone (Fig. 3, profiles 3 and 4) was related to continent-island arc collision [27].

In the Late Paleozoic, these reverse faults were transformed into the Syuren thrust system and its splay reverse faults and retrothrusts (Fig. 3, profiles 5-8).

We are inclined to believe that the Syurenskii upthrust system, which is the natural western boundary of the Ural Frontal Fold Zone, formed in relation to the continent-continent collision (just like the epiPaleozoic Ural orogen during the Hercynian orogeny in the Late Paleozoic) $[6,7,27,29]$.

The Syuren upthrust system is morphologically diverse and, hence, differs in areas north and south of the Sakmara River (Fig. 4). From north to south, the folding surface of the Ural Frontal Folds also gradually deepens, the size and amplitude of individual folds increase, and the intensity of small folds superimposed on their limbs and plication simultaneously diminish.

Within the Ural Frontal Fold Zone, series of conjugate harmonic (in the eastern part of the Ural Frontal Fold Zone) and disharmonic (in the central and western parts of the zone) folds are related to the Syuren reverse fault-thrust system. Typical folds in the Ural Frontal Fold Zone are long (up to $60 \mathrm{~km}$ ) and narrow (no wider than $2 \mathrm{~km}$ ) linear undulating eject [18] anticlines with north-northwestern or meridional strike with en echelon axes (Fig. 4). The western limbs of the folds dip at steeper angles than the eastern ones. The anticlines occur together with broad U-shaped synclines. The limbs of large folds are overlapped by smaller folds and longitudinal thrusts with western vergence and by retrothrusts whose fault planes dip westward and which are minor faults of the Syurenskii upthrust system.

The results of our geomechanical modeling have allowed us to distinguish the following four fault types in the Ural Frontal Fold Zone: (1) Syuren upthrust;

Fig. 3. Geomechanical modeling along line transverse to strike of Ural Frontal Folds. Paleoprofiles (circled numerals) as of: (1) beginning of Devonian; (2) beginning of earliest Carboniferous; (3) beginning of Middle Carboniferous; (4) beginning of Late Carboniferous; (5) Asselian age, Early Permian; (6) beginning of Sakmarian age, Early Permian; (7) beginning of Artinskian age, Early Permian; (8) beginning of Kungurian age, Early Permian (before erosion); (9) today. (1) faults; (2) erosion surface; (3) displacement direction along fault.

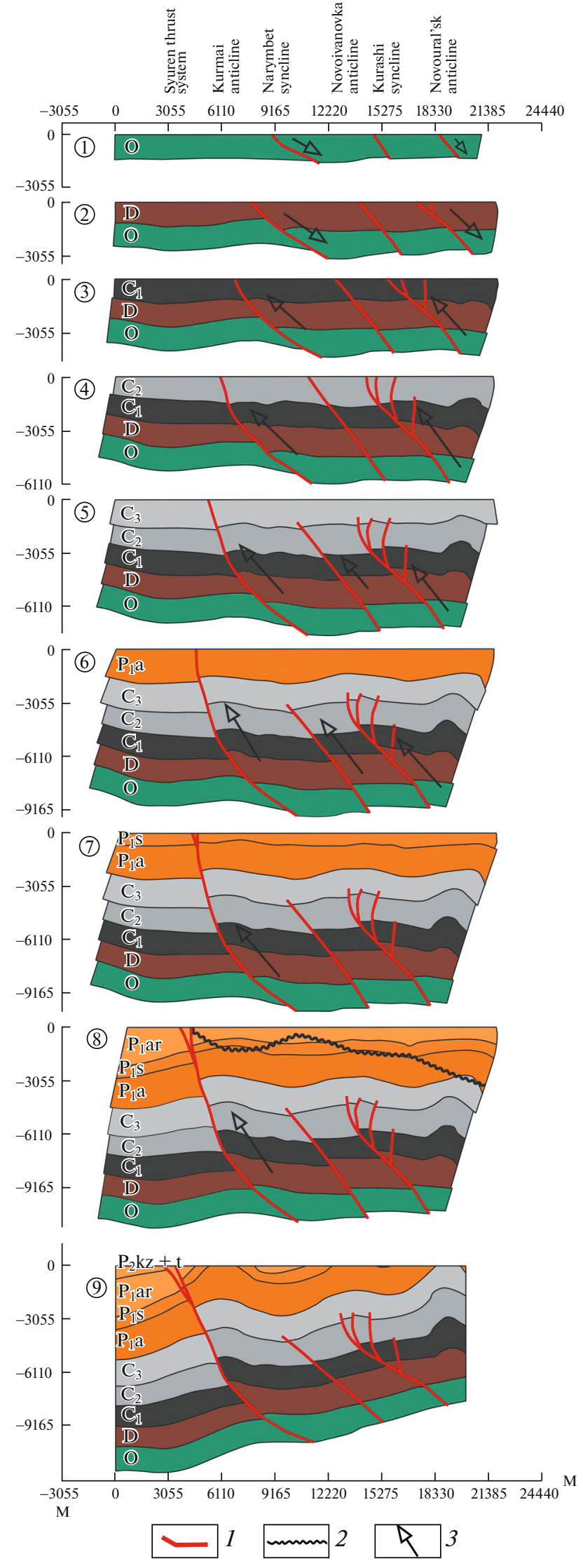


(2) splay faults of the Syuren upthrust fault; (3) penetrating faults (as in the western flank of the Bel'skaya Depression); and (4) subvertical intraformational faults.

The most contrasting (high-amplitude) tectonic feature of the upthrust system is the Syuren upthrust itself. The upper part of its fault surface is nearly vertical, and this surface is inclined at gentler angles at lower structural floors.

Tectonic blocks were displaced in different ways along splay faults of the Syuren upthrust, and this resulted in a system of en echelon blocks. Some of the reverse and normal faults seem to be randomly oriented, and the harmonic folds in the Ural Frontal Fold Zone conceivably may have formed in association with the splay faults of the Syuren upthrust.

\section{MODELS OF THE PETROLEUM SYSTEMS}

Our models for the petroleum systems (Fig. 5) indicate that hydrocarbons of the subthrust zones and frontal folds in the Urals originated from source rocks in the Bel'skii and Sol'-Iletsk (Caspian) hydrocarbon generation regions in the petroleum systems of the Ural Foredeep. Hydrocarbons migrated from these regions toward the subthrust zones of the Ural Foredeep and Ural Frontal Fold Zone.

The results of our basin modeling and analysis of geochemical data suggest that the following petroleum systems operated in the area: Ordovician-Silurian, Lower Devonian-Frasnian, Frasnian-Tournaisian, Visean-Bashkirian, and Lower Permian.

The most probable source rocks of the Lower Devonian-Frasnian petroleum system are Givetian and Eifelian sedimentary rocks in the Ural Foredeep. The source rocks first reached the oil window in the Early Triassic (in the eastern part of the Ural Foredeep). The rocks reached the main gas-generation zone in the mid-Triassic. The maturity of organic matter (total organic carbon, TOC) of source rocks in most of the southern segment of the Ural Foredeep currently corresponds to the main oil-generation zone
(Fig. 5a). In the southern part of the area, source rocks occur mostly in the gas-generation zone.

The Frasnian-Tournaisian petroleum system encompasses rocks whose age ranges from the midupper Frasnian through the Tournaisian of the Early Carboniferous. The source rocks of this system are Domanikian-type rocks of the Semilukian horizon (of mid-Frasnian age, Late Devonian). In the deepest parts of the Ural Foredeep, source rocks occur mostly in the gas-generation zone (Fig. 5b), and the maturity of organic matter in the rest of the territory corresponds to the main oil-generation zone. The transformation of kerogen now significantly varies, and the transformation ratio $T R$ (the degree of transformation of the original generation potential of a source rock) never exceeds $85 \%$.

The Visean-Bashkirian petroleum system comprises Late Visean carbonate rocks and carbonate strata of the Tulian, Serpukhovian (Lower Carboniferous), and Bashkirian (Middle Carboniferous) rocks. The identified Visean source rocks formed in a strongly reduced geochemical environment, which was favorable to the accumulation and preservation of organic matter. In most of the Ural Foredeep territory, source rocks occur in the dominant oil-generation zone. Within a relatively small area, the source rocks have left the main oil-generation zone. The relationships between the timing of trap production and hydrocarbon generation, migration, and accumulations are favorable. $T R$ for kerogen currently vary from 0 to $70 \%$, and $T R$ in the deepest rocks generally ranges from 40 to $60 \%$ on average. The transformation processes gradually intensified from the mid-Triassic to the late Paleogene. As follows from organic matter maturity maps of the source rocks (Fig. 5c) of the Visean-Bashkirian petroleum system, the maturity of organic matter (TOC) within most of the territory corresponds to the oil window.

The source rocks of the Lower Permian petroleum system in the deepest parts of the foredeep occur in the dominant liquid-hydrocarbon generation zone (Fig. 5d). In the rest of the territory, the organic mat-

Fig. 4. Schematic geological map of Ural Frontal Fold Zone and adjacent structural zones (composed using data from [2, 18]). Frontal Folds of Urals (circled numerals): (1) Kurmai anticline; (2) Aktakal (Antakol) anticline; (3) Chumaza syncline; (4) Belgushka anticline; (5) Narymbet syncline; (6) Abazovskaya syncline; (7) Saployak anticline; (8) Novoivanovka (Dubenskaya) anticline; (9) Buzhan syncline; (10) Kurashi syncline; (11) Novoural'sk anticline; (12) Yuldashevo anticline; (13) Mukhamed'yarovo syncline; (14) Novomikhailovka anticline; (15) Nikol'skaya syncline; (16) Chiili (Azan-Tash) anticline; (17) Kanshary syncline; (18) Barangulovo anticline; (19) Il'inka syncline; (20) Kimpersai-Alimbet syncline; (21) Kuruil-Alimbet anticline; (22) Adaevo syncline; (23) Tlyavgulovo anticline; (24) Novosamarsk syncline; (25) Kashkuk anticline; (26-28) unnamed folds. Legend: (1) Pliocene-Quaternary mostly alluvial rocks; (2) Miocene-Cretaceous rocks; (3) Jurassic rocks; (4) Triassic rocks; (5) combined post-Kungurian Permian rocks (continental molasse); (6) combined Kungurian-Sakmarian rocks; (7) combined Asselian-Late Carboniferous rocks; $(8)$ combined Middle Carboniferous rocks; (9) combined Serpukhovian-Visean rocks; (10) Tournaisian-Famennian rocks (Zilair group, graywacke flysch); (11) combined Early-Middle Paleozoic volcanic, volcanic-sedimentary, and sedimentary rocks and ophiolites (Sakmara zone); (12) combined Late Precambrian (?) and Early-Middle Paleozoic unequally metamorphosed sedimentary and volcanic-sedimentary rocks of the Maksyutovo and Suvanyak complexes (Uraltau zone); (13) local oil- and gas-geological structures in subsalt rocks; (14) major faults: (a) thrust in the bottom part of the Sakmara allochthon, (b) Syuren thrust; (15) other faults: $(a)$ splay upthrusts (of western vergence) of the Syuren thrust, $(b)$ steep faults: combined normal, reverse, and strike-slip faults; (16) axes (hinge projections onto the horizontal plane) of individual folds in Ural Frontal Fold Zone: $(a)$ anticlines, $(b)$ synclines; (17) boreholes and wells. 


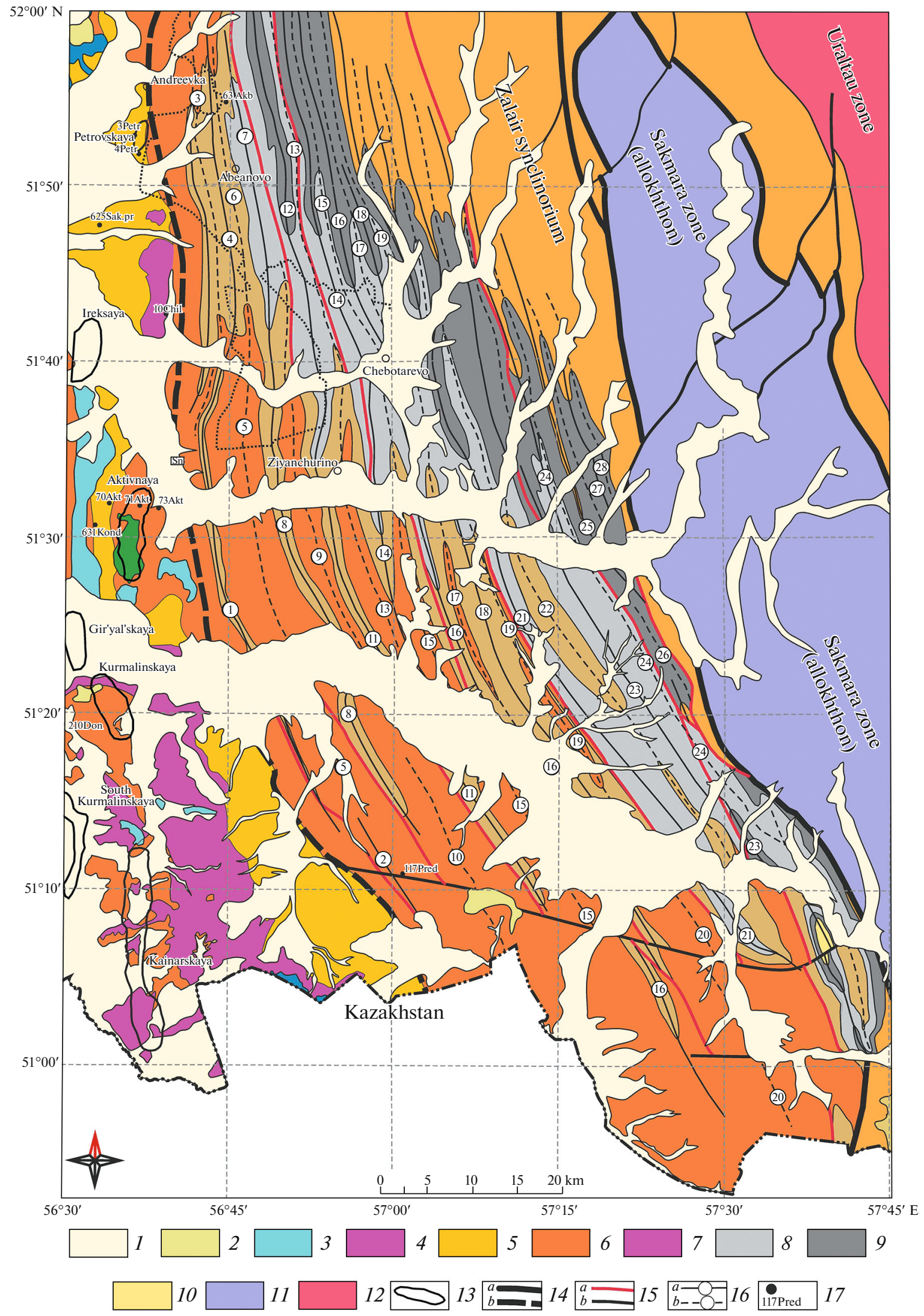


ter of Lower Permian rocks is immature. The high quality of kerogen governed the generation of mostly liquid hydrocarbons in the predicted accumulations of this petroleum system. The transformation of kerogen in Lower Permian source rocks is currently somewhat more significant than in the ViseanBashkirian source petroleum system. In the deepest parts of the foredeep, $T R$ reaches $70-80 \%$.

Analysis of our 3D models for the transformation of organic matter (TOC) allowed us to identify two hydrocarbon generation regions. One is constrained to the southern part of the Ural Foredeep, and the other occurs in the Sol'-Iletsk dome.

\section{DISCUSSION}

The consensus among various researchers in understanding the Late Precambrian and Paleozoic geodynamic evolutionary history of the Ural-Novaya Zemlya Fold Belt stems largely from the fact that the Late Precambrian and Paleozoic complexes of the Urals show relatively simple tectonic zoning. Late Precambrian rocks are found mostly in the western Urals and are characterized by latitudinal tectonic zoning: the southern segments of the Urals are dominated by Late Precambrian sedimentary rocks [44], and conversely, its northern segments largely are made up of Late Precambrian volcanics, various granitoids, and rare ophiolites $[4,5,16,33,34,41]$. The rocks were produced in association with Late Precambrian subduction-obduction and Vendian-Early Cambrian collisional geodynamic processes [13].

The Paleozoic complexes and structures of the Urals also exhibit relatively simple meridional tectonic zoning. The western tectonic units of the Urals consist mostly of Paleozoic sedimentary rocks [5, 7, 27], whereas the eastern zones, conversely, show widespread Paleozoic ophiolites, arc rocks, and collisional granites. The geodynamic nature of rocks in the eastern zones of the Urals is reportedly related to Early Paleozoic [21, 30] and mid-Paleozoic [6, 14, 15, 17, 31] subductionobduction processes and with Late Paleozoic collisional events $[6,27]$.

In the Pai Khoi and Novaya Zemlya segments of the Ural-Novaya Zemlya Fold Belt, no rock complexes were found with compositions, tectonics, and geodynamics similar to those of the Paleozoic complexes in the eastern tectonic units of the Urals [22, 38, 39]; i.e., neither Paleozoic ophiolites nor ophiolite complexes have ever been identified in the Pai Khoi and Novaya Zemlya segments. Therefore, the relationships between the origin of the Pai Khoi and Novaya Zemlya parts of the Ural-Novaya Zemlya Fold Belt with Paleozoic subduction-obduction and collisional geodynamic processes are not evident. Moreover, it has been established [27] that fold-thrust structures in the Pai Khoi and Novaya Zemlya segments formed not in the Late Paleozoic (like in the
Urals) but in the mid-Mesozoic (during the late Cimmerian orogeny).

In spite of this, the Ural and Pai Khoi-Novaya Zemlya parts of the Ural-Novaya Zemlya Fold Belt exhibit certain common structural features: similarities in the composition and internal structure of Paleozoic rocks in the Pai Khoi and Novaya Zemlya segments with coeval rocks in the western zones of the Urals and the occurrence of a common foredeep throughout the entire length of the Ural-Novaya Zemlya Fold Belt. The Ural, Pai Khoi, and Novaya Zemlya parts of the foredeep are referred to, respectively, as the Ural Foredeep, Pai Khoi Foredeep, and Novaya Zemlya Foredeep.

Parts of the Ural-Novaya Zemlya Foredeep close to structures of the Ural-Novaya Zemlya Forebelt of Oil and Gas Accumulations are characterized by intense folding, reverse faulting, and thrusting, whose vergence is directed away from the Ural-Novaya Zemlya Fold Belt. Seismic data (as well as local drilling materials) indicate that folded, reverse-faulted, and thrust rocks in the eastern areas and the eastern surroundings of the belt are underlain by weakly deformed and/or horizontal rock strata. These are platform-type Lower and Middle Paleozoic formations (including potentially oil-bearing ones), which are similar to formations characteristic of passive continental margins, as well as Upper Paleozoic (and Middle Mesozoic in the north) orogenic formations.

These formations, which are tectonically overlain by folded, reverse-faulted, and thrust structures of the eastern flank of the Ural-Pai Khoi-Novaya Zemlya Foredeep and similarly deformed Paleozoic (and locally Late Cambrian) complexes of trans-Ural tectonic units and their compositional and stratigraphic analogs found in the Pai Khoi and western Novaya Zemlya segments, locally occur at depths as shallow as $3-4 \mathrm{~km}$. Thus, the weakly deformed and potentially oil- and gas-bearing complexes in the eastern part of the Ural-Novaya Zemlya Forebelt occur at depths readily accessible to drilling. It has been revealed that similar formations in nearby areas of the ancient (epiKarelian) East European Platform and the young (epi-Timanian) Timan-Pechora-Southern Barents Sea Platform host oil, gas, and gas condensate fields.

Some wells drilled in the eastern part of the UralNovaya Zemlya Forebelt of Oil and Gas Accumulations through the subthrust formations have revealed intense oil and gas manifestations in formations beneath allochthonous fold-thrust systems, suggesting that occurrences of oil and gas pools in the area. This also gives grounds to expect findings of new hydrocarbon accumulations in subthrust zones in the western Urals, southwestern Pai Khoi, and western Novaya Zemlya orogen.

Data on the geology of the junction zone of the Paleozoides in the Southern Urals and the southeastern part of the East European Platform show [27] that 
(a)

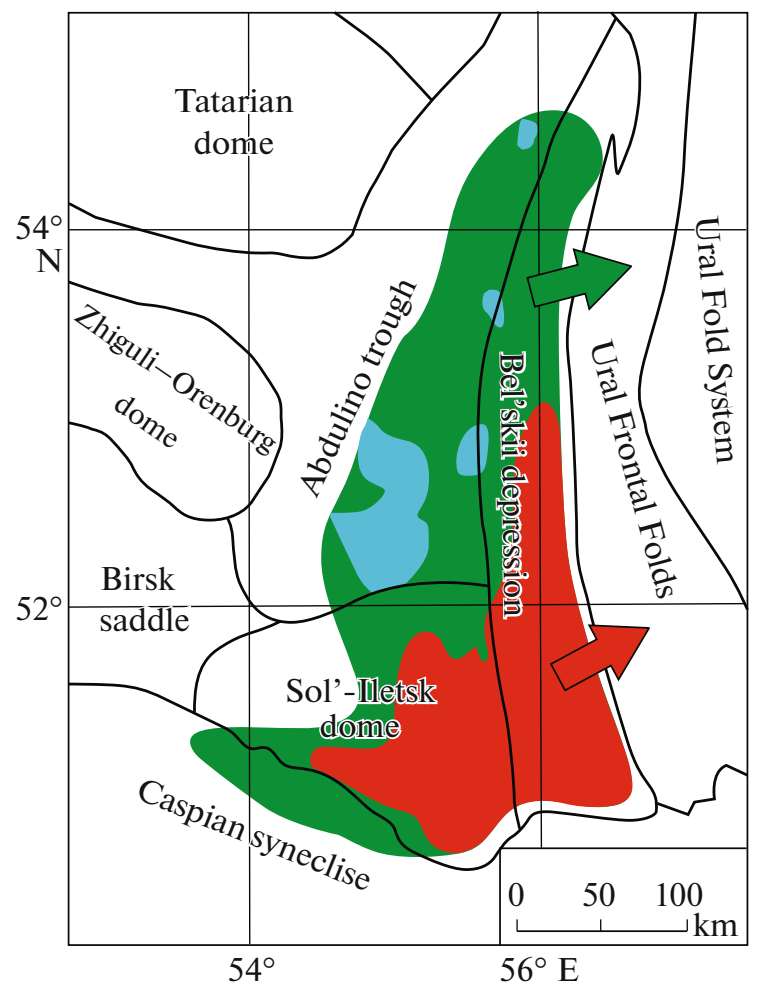

(c)

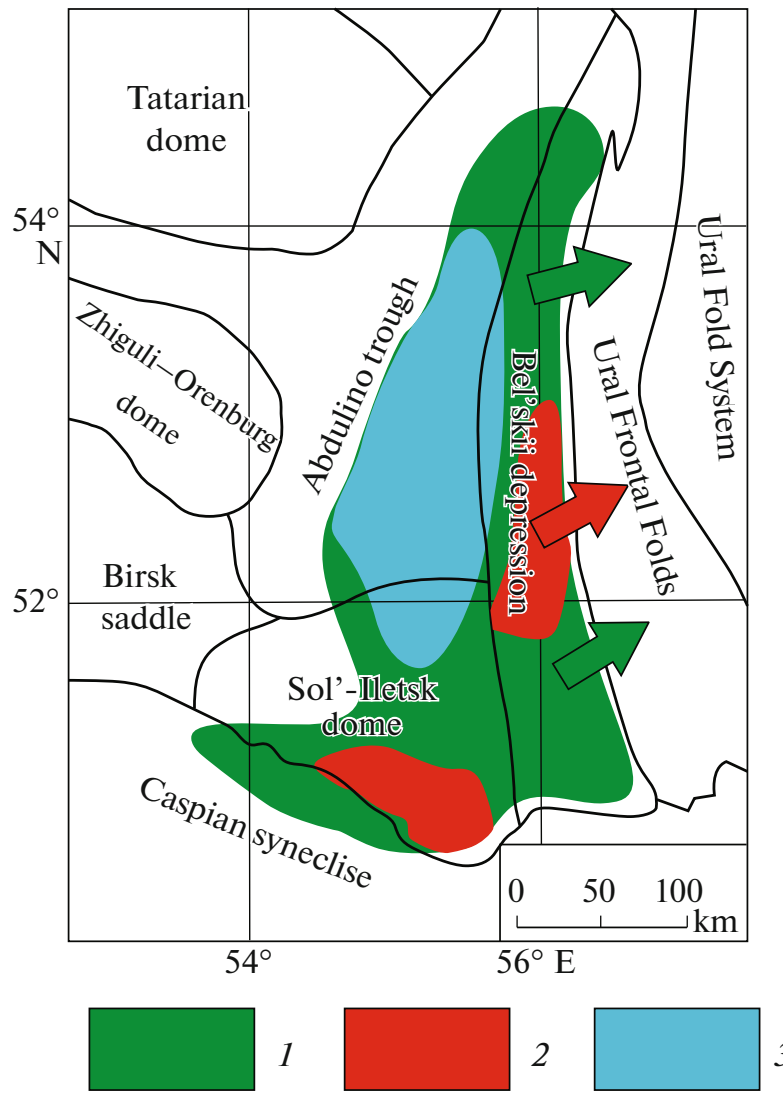

(b)

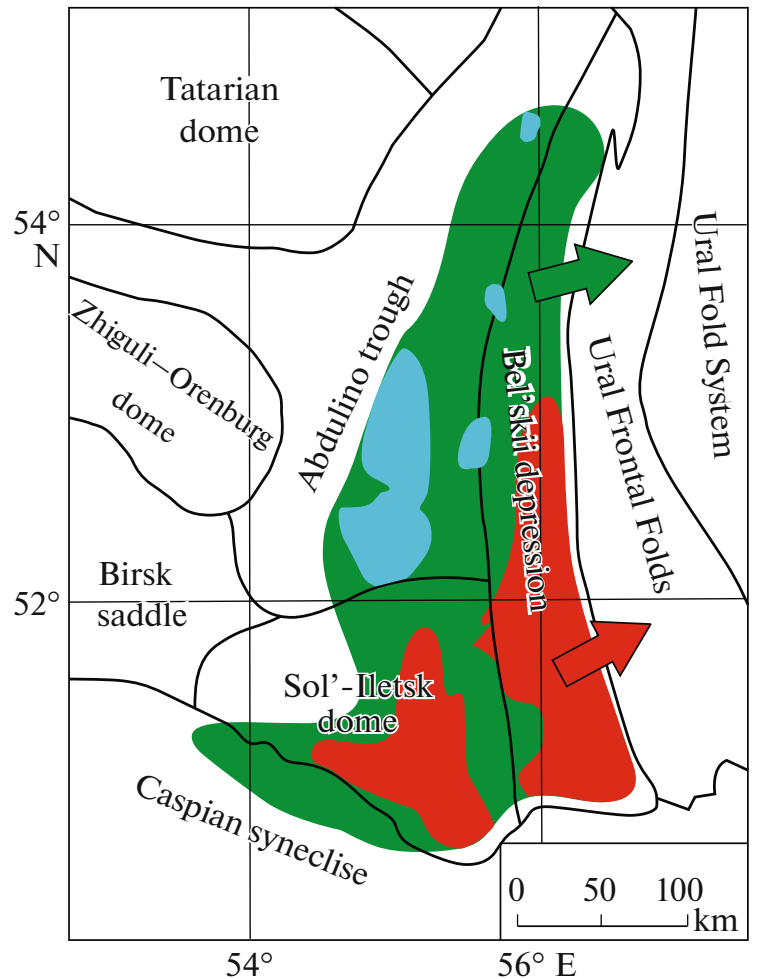

(d)

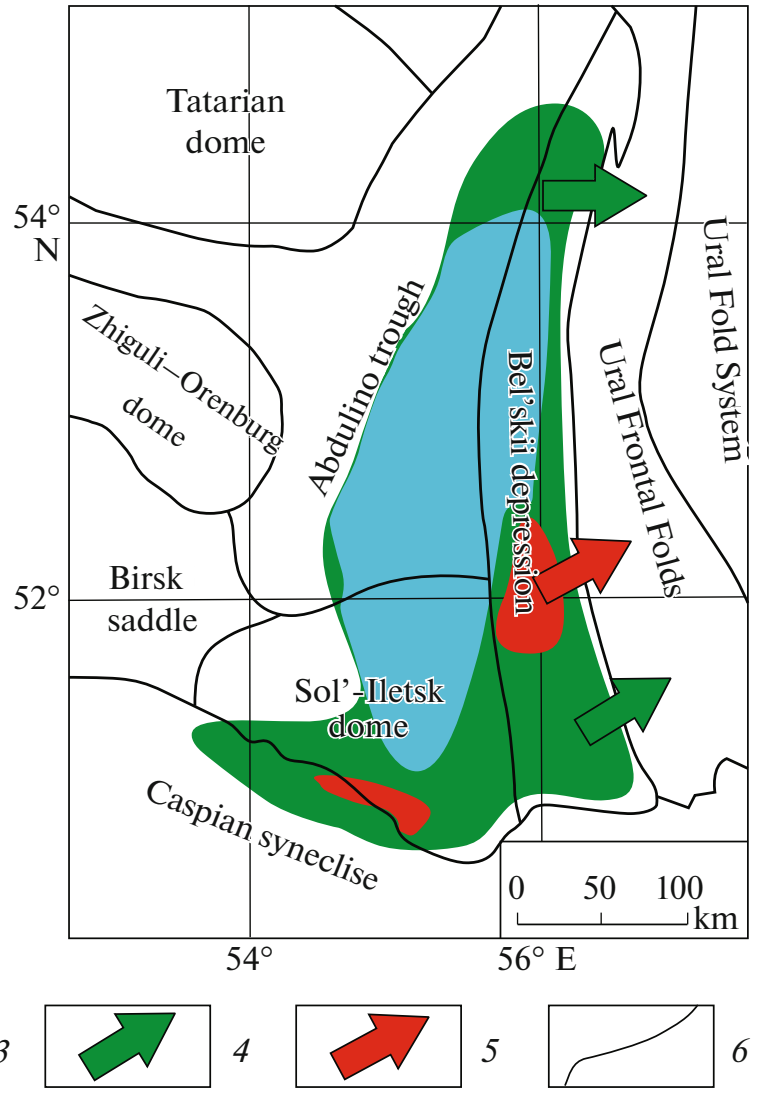

Fig. 5. Maps of petroleum systems based on results of 3D modeling: (a) Early Devonian-Frasnian; (b) Frasnian-Tournaisian, (c) Visean-Bashkirian; (d) Early Permian. (1) Oil generation regions, (2) gas generation regions, (3) oil and gas source rocks with immature organic matter (no hydrocarbons are generated); (4) oil migration; (5) gas migration; (6) boundaries of tectonic elements. 
the eastern flank of the Southern Ural segment of the Ural Foredeep (eastern wall of the Bel'skaya Depression of the Ural Foredeep) is significantly disturbed by folds and faults with western vergence. The rocks of the foredeep and adjacent parts of the Western Ural Zone make up the so-called Frontal Fold Zone of the Urals (Western Ural Linear Fold Zone). The internal structure of this zone involves a system of upthrusts and underthrusts along which the complexes of West Ural Zone were thrust westward (Fig. 4). These deformations, together with genetically related systems of conjugate anticlines and synclines of various size, were formed by horizontal compression directed from the paleo-Ural orogen and were caused by the Late Paleozoic geotectonic regime.

A series of seismic geological profiles was constructed based on interpretations of regional-scale seismic operations conducted in the Frontal Fold Zone of the western Urals (Western Ural Linear Fold Zone) in 2011-2013 [23]. Some of these profiles are latitudinal and run across the junction zone of the eastern flank of the Bel'skaya Depression in the Ural Foredeep and the Western Ural Linear Fold Zone (Ural Frontal Fold Zone) (Fig. 6).

Preexisting regional seismic-stratigraphic models [23] cannot always provide a clear understanding of the internal structure of the eastern flank of the southern segment of the Ural Foredeep, because Paleozoic formations in the area were uplifted toward the Ural Frontal Fold Zone and crop out in this zone, making up a folded structure complicated by upthrusts.

In estimating the oil and gas potential of the Ural Frontal Fold Zone as a part of the Ural Fold Belt, one should consider that this part of the Urals is made up of different Paleozoic formations. Lower and Middle Paleozoic rocks formed on the passive margin of the East European continent [6, 7, 27]. Other researchers believe that Lower and Middle Paleozoic rocks in the area accumulated on the nearby flank of an extensive marginal-sea basin that developed in the Early and Middle Paleozoic in the rear zone of the suprasubduction system that occurred in the transition zone from the Ural paleoocean to the East European part of the Arct-Laurussia paleocontinent [13]. Late Paleozoic formations are found in the Ural Frontal Fold Zone and in various zones of the foredeep, including its distal and even depression zones (bottom parts of the Late Paleozoic sedimentary sequence), as well as in proximal zones (upper parts of the Late Paleozoic sequence). This means that the Early Paleozoic stratigraphic units, particularly, in the bottom part of the Late Paleozoic stratigraphic sequences, include potential oil- and gas-bearing formations. These formations accumulated in the distal parts of the sedimentary basin on the Late Paleozoic passive margin or marginal sea, as well as in distal and/or even depression zones of the Late Paleozoic foredeep during its early evolution. The top parts of the Upper Paleozoic sequence are dominated by coarse clastic rocks (which are potential hydrocarbon reservoirs), because during the evolution of the Ural collision (Hercynian orogenesis), ever growing volumes of terrigenous material were brought from the paleo-Ural orogen into the foredeep (Ural marginal deep), and this material was accumulated in proximal parts of its eastern flank. As the orogen evolved, the depocenter of the basin shifted westward, and its eastern wall was affected by progressively intensified folding and upthrusting, up to tectonic overlay in the easternmost zones.

The territory thus has acquired all features necessary for a petroleum system: potential source rocks, potential reservoir rocks, potential seals for fluids, and potential structural traps (tectonically sealed traps).

It seems obvious that accretionary and collisional tectonic processes during arc-continent collision resulted in increased regional heat flux. The tectonic doubling of the stratigraphic sequence in the eastern flank of the Ural foredeep, particularly in the Ural Frontal Fold Zone, caused rapid subsidence and significant heating of source rocks. The environments in the eastern flank of the Ural Foredeep were favorable to the rapid transformation of organic matter (TOC) disseminated in source rocks into hydrocarbon fluids: liquid and gaseous hydrocarbons.

An important structural feature of the eastern flank of the Ural Foredeep throughout its entire length was multistory thrust systems with western vergence, along which multiple tectonic thickening (tectonic multiplication) of the stratigraphic sequence took place. Among others, these were tectonic inthrusts found in the area [35], or gently dipping tectonic duplexes: socalled crock mouth-type structures found in the frontal parts of some thrusts [36, 37].

Systems of detachment surfaces mark large-amplitude horizontal detachments and the development of structural disharmony at the upper structural levels relative to lower ones (Figs. 3,6). The high intensity of deformations was favorable to fracturing; i.e., these deformations produced secondary tectonic porosity and permeability of rocks, which improved their characteristics as hydrocarbon reservoirs. This might have also increased the permeability of fault zones and transformed them into feeder (permeable) zones for vertical and horizontal hydrocarbon fluid flows.

Analysis of the origin of hydrocarbon accumulations in upthrust and subthrust zones $[10,48]$ and the results of our geomechanical modeling has led us to suggest a concept for the origin of hydrocarbon accumulations in these zones (Fig. 7) according to which, oil and gas accumulations were produced during the following five stages.

First, Ordovician-Lower Permian rocks accumulated during the consedimentation stage. Some of these rocks contained a large amount of organic matter (TOC) and thus served as source rocks for future petroleum systems. 

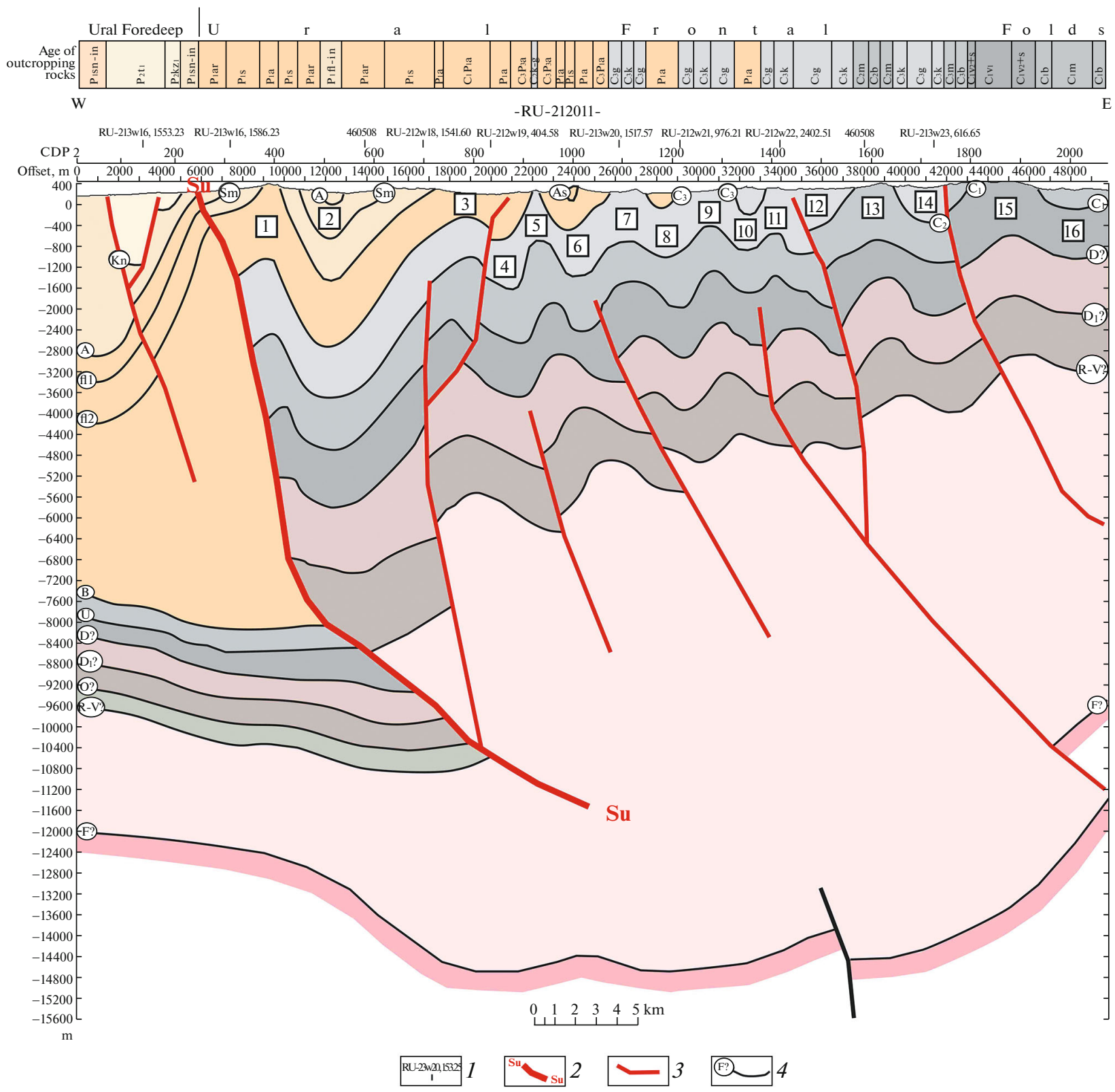

Fig. 6. Seismic-geological vertical section along latitudinal profile RU-212011 across southern flank of southern segment of Ural Foredeep and Ural Frontal Fold Zone (compiled with data from [23]). Ural Frontal Folds (circled numerals): (1) Kurmai anticline; (2) Narymbet syncline; (3) Novoivanovka anticline; (4) Buzhan syncline; (5) Novoural'sk anticline; (6) Mukhamed'yarovo syncline; (7) Novomikhailovka anticline; (8) Nikol'skaya syncline; (9) Chiili anticline; (10) Kanshary syncline; (11) Barangulovo anticline; (12) Il'inka syncline; (13) Kuruil-Alimbet; (14) Adaevo syncline; (15) Tlyavgulovo anthropogenic; (16) Novosamarsk syncline. Legend: (1) intersection of seismic profiles; (2) Syuren upthrust; (3) faults; (4) seismic benchmarks on tops of: Kn means Irenskii Horizon, Kungurian Stage, Lower Permian; A, Saraninskii Horizon, Kungurian Stage, Lower Permian; Sm, Sakmarian Stage, Lower Permian; As, Asselian Stage, Lower Permian; $\mathrm{C}_{3}$, Upper Carboniferous; $\mathrm{C}_{2}$, Middle Carboniferous; $\mathrm{C}_{1}$, Lower Carboniferous; D?, Eifelian Stage, Middle Devonian; $\mathrm{D}_{1}$ ?, Lower Devonian; R-V?, Riphean-Vendian rocks, F?, crystalline basement.

Second, accretion-obduction and collision processes that began in the latest Devonian (in the Famennian) and proceeded in the Carboniferous through the Early Permian in the more eastern zones of the Urals, caused upthrusting. As a result, traps were formed in the sealed subthrust folds.
Third, hydrocarbons were generated and charged the traps in the latest Permian.

Fourth, hydrocarbons accumulated in and filled the traps in the Triassic and Jurassic.

Fifth, the hydrocarbon accumulations were conserved in the Late Mesozoic and Cenozoic. Neotec- 
(5)

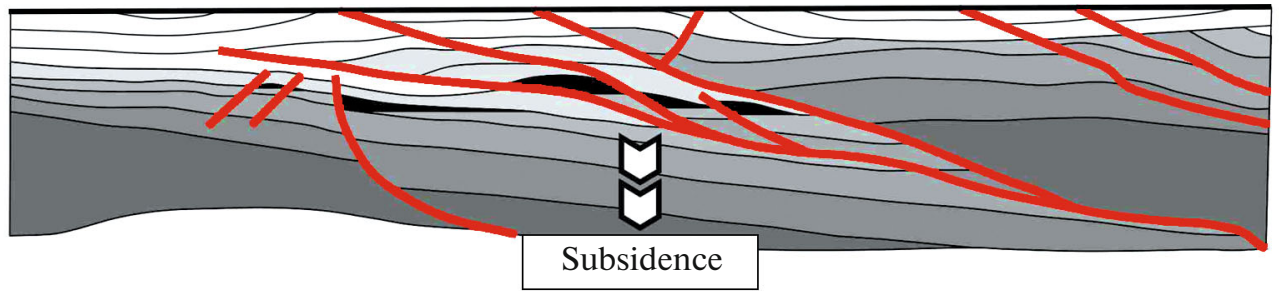

(4)

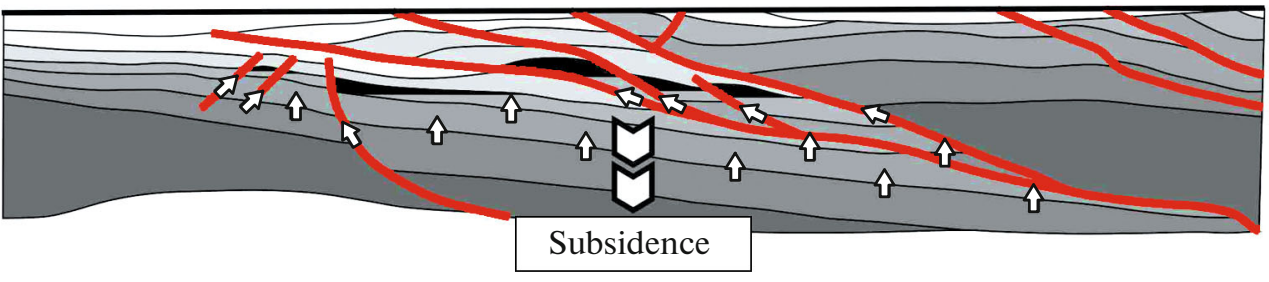

(3)

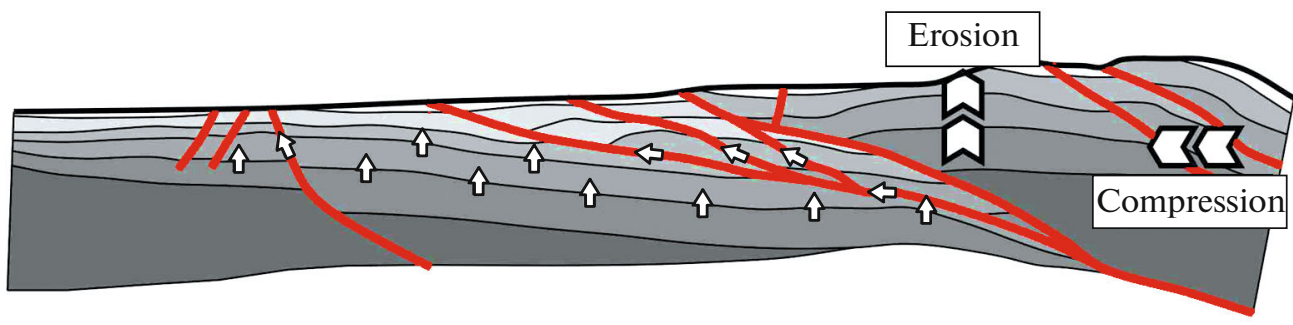

(2)

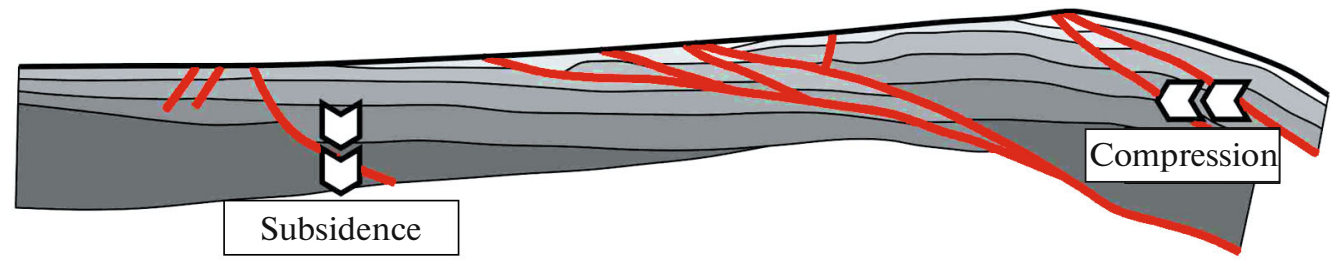

(1)
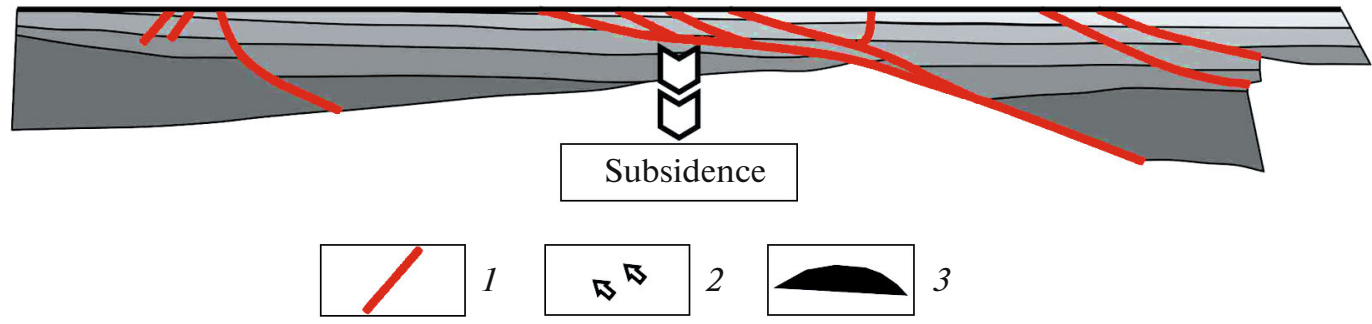

Fig. 7. Conceptual model for origin of hydrocarbon accumulations in upthrust structures. Evolutionary stages (circled numerals): (1) deposition of sedimentary complex; (2) development of upthrusts and traps in subthrust folds; (3) migration of hydrocarbons to traps; (4) accumulation of hydrocarbon in traps; (5) conservation of hydrocarbon accumulations. Legend: (1) faults; (2) migration of hydrocarbons; (3) hydrocarbon accumulations.

tonic processes during that time could have destroyed some of the preexisting oil and gas pools.

Additional factors that controlled the origin of hydrocarbon accumulations in the upthrust zones in the eastern zones of the Ural Foredeep were related to heat generation and intense tectonic fracturing due to strong stress. This stress was induced by accretionaryobductional and collisional tectonism and resulted in subhorizontal stratification of sedimentary rocks and active differential motions (frontal thrusting and lateral squeezing of more plastic rocks) along these zones.

The long (mostly horizontal) faults that bound the nappes from above and below channeled fluid migration flows. Hydrocarbon migration was facilitated by a pressure decrease in cutting fracture zones. This resulted in contrasting conditions with great pressure 
gradients, enhanced the mobility of the fluids, and enabled them to migrate from regions of elevated pressure. Moreover, the thickness of the deformation wedge of sedimentary rocks was greater in the eastern parts of the fold belt; hence, sedimentary rocks were there more intensely tectonized and heated. Consequently, these rocks could have also been involved in expelling hydrocarbons, and faults and fractures facilitated this process. The intense reverse faulting and thrusting of the area thus predetermined the development of regions (zones), along with additional generation zones, discharge zones, and a favorably fluid-dynamic regime and pathways, which ensured hydrocarbon migration to accumulation sites. Calculations indicate that the structural restyling of the sedimentary basin, including upthrusting, relocated some of the hydrocarbon accumulations by lateral or ascending oil and gas flows from the primary to newly formed traps. Upthrusts should thus be reviewed as extremely important oil- and gas-controlling features of this regional thrust and fold structure.

\section{CONCLUSIONS}

(1) Seismic profiles were interpreted to construct a detailed geological profile of the region and its seismic-geological sections. This vertical profile shows all principal structural zones of the Ural Frontal Fold Zone. Two-dimensional geomechanical modeling conducted for this profile demonstrates the subsidence dynamics of the bottom of the basin, the accumulation of its sedimentary filling material, and the development of folding and upthrusting, which significantly complicated the architecture of sedimentary sequences in the Ural Foredeep.

(2) We have proved that structural tectonically sealed traps and potential hydrocarbon accumulations could have been produced in upthrust and subthrust structures.

(3) We have proved that the relationships between the generation, migration, and accumulation of hydrocarbons and the origin of traps in the area were favorable to the origin of hydrocarbon accumulations. The main features of petroleum systems (source rocks, reservoir rocks, seal rocks, and traps) in the area (in the Ural Frontal Fold Zone and the southern segment of the Ural Foredeep) formed by the end of the Permian. Starting in the Triassic, hydrocarbon fluids were generated and migrated from the source rocks.

Our results indicate that the newly discovered hydrocarbon accumulations in the eastern part of the Southern Ural and Ural-Novaya Zemlya Fore Belt of Oil and Gas Accumulations are highly promising.

\section{OPEN ACCESS}

This article is distributed under the terms of the Creative Commons Attribution 4.0 International License (http://creativecommons.org/licenses/by/4.0/), which permits unrestricted use, distribution, and reproduction in any medium, provided you give appropriate credit to the original author(s) and the source, provide a link to the Creative Commons license, and indicate if changes were made.

\section{ACKNOWLEDGMENTS}

This study was supported by the Ministry of Education and Science of the Russian Federation (government-financed projects 5.2907.2017/4.6 of the Gubkin University and 0135-2016-0009 of the Geological Institute, Russian Academy of Sciences).

\section{REFERENCES}

1. M. M. Buslov, "Tectonics and geodynamics of the Central Asian Foldbelt: The role of Late Paleozoic large-amplitude strike-slip faults," Russ. Geol. Geophys. 52, 52-71 (2011).

2. V. V. Vingalov, V. V. Drozdov, Yu. M. Kuteev, et al., Basin Modeling of the Fore-Uralian Foredeep and Folded Ural within the Limits of Orenburg Oblast in Order to Choose Promising Directions of Search for Oil and Gas Fields (Sibgeoproekt, Tyumen, 2014) [in Russian].

3. V. P. Gavrilov, "Geodynamic model of oil and gas formation in the lithosphere and its implications," Geol. Nefti Gaza, No. 6, 2-12 (1998).

4. V. A. Dushin, Magmatism and Geodynamics of the Paleocontinental Sector of the Northern Urals (Nedra, Moscow, 1997) [in Russian].

5. L. P. Zonenshain, M. I. Kuz'min, and L. M. Natapov, Lithosphere Plate Tectonics of the USSR Territory, 2 Vols. (Nedra, Moscow, 1990) [in Russian].

6. K. S. Ivanov, Doctoral Dissertation in Geology and Mineralogy (Inst. Geol. Geokhim. Ural. Otd. Ross. Akad. Nauk, Yekaterinburg, 1998) [in Russian].

7. S. N. Ivanov, V. N. Puchkov, K. S. Ivanov, G. I. Samarkin, I. V. Semenov, A. I. Pumpyanskii, A. M. Dymkin, Yu. A. Poltavets, A. I. Rusin, and A. A. Krasnobaev, Formation of the Earth's Crust of the Urals (Nauka, Moscow, 1986) [in Russian].

8. R. A. Ismagilov, I. M. Farkhutdinov, A. M. Farkhutdinov, and L. A. Khairulina, "Tectonics and perspectives of oil and gas potential of the junction zone between Yuryuzan-Sylva depression and Ufa amphitheater," Georesursy 2 (3), 43-48 (2015).

9. V. Yu. Kerimov, A. A. Gorbunov, E. A. Lavrenova, and A. V. Osipov, "Models of hydrocarbon systems in the Russian Platform-Ural junction zone," Lithol. Miner. Resour. 50, 394-406 (2015).

10. V. Yu. Kerimov, N. B. Kuznetsov, R. N. Mustaev, A. V. Osipov, A. V. Bondarev, and A. S. Nefedova, "Formation condition of hydrocarbon reservoirs in uphrow-thrust structures in the eastern side of the ForeUralian Foredeep," Neft. Khoz., No. 7, 36-41 (2017).

11. V. Yu. Kerimov, M. Z. Rachinsky, R. N. Mustaev, and A. V. Osipov, "Groundwater dynamic forecasting criteria of oil and gas occurrences in Apline mobile belt basins," Dokl. Earth Sci. 476, 1066-1068 (2017). 
12. V. Yu. Kerimov and M. Z. Rachinsky, "Geofluid dynamic concept of hydrocarbon accumulation in natural reservoirs," Dokl. Earth Sci. 471, 1123-1125 (2016).

13. N. B. Kuznetsov, "Cambrian collision of the Baltic and Arctida as the initial stage of assembling the northern part of Pangea in the Late Paleozoic-Early Mesozoic," Byull. Mosk. O-va. Ispyt. Prir., Otd. Geol. 84 (1), 1838 (2009).

14. N. B. Kuznetsov and K. V. Kulikova, "Complexes and structures of the Syumkeu-Shchuch'ya area of the Polar Urals. Part 1. Tectonically structure of the Syumkeu-Shchuch'ya area of the Polar Urals," Byull. Mosk. O-va. Ispyt. Prir., Otd. Geol. 83 (3), 3-12 (2008).

15. N. B. Kuznetsov and T. V. Romanyuk, "Paleozoic evolution of the Polar Urals: Voikar Basin with oceanic crust had been being existed for at least $65 \mathrm{Ma}$," Byull. Mosk. O-va. Ispyt. Prir., Otd. Geol. 89 (5), 56-70 (2014)

16. N. B. Kuznetsov, A. A. Soboleva, O. V. Udoratina, M. V. Gertseva, V. L. Andreichev, and N. S. Dorokhov, "Pre-Uralian tectonic evolution of the northeastern and eastern frames of the East European Craton. Part 2. Late Precambrian-Cambrian collision between Baltica and Arctida," Litosfera, No. 1, 32-45 (2007).

17. K. V. Kulikova and N. B. Kuznetsov, "Complexes and structures of the Syumkeu-Shchuch'ya area of the Polar Urals. Part 2. Typification of gabbroids from the Syumkeu-Shchuch'ya area of the Polar Urals and the nature of their metamorphic transformations," Byull. Mosk. O-va. Ispyt. Prir., Otd. Geol. 83 (4), 12-24 (2008)

18. P. V. Lyadskii, L. N. Kvasnyuk, A. V. Zhdanov, O. V. Chechulina, et al., State Geological Map of Russian Federation, Scale 1: 1000000 (Third Generation). Uralian Series. Explanatory Note (VSEGEI, St. Petersburg, 2013) [in Russian].

19. M. V. Muratov, "Geosyncline fold belts of Eurasia," Geotektonika, No. 6, 4-19 (1965).

20. E. I. Pankratova and B. P. Bogdanov, "Geological background of revealing bed reservoirs in Lower PermianCarboniferous deposits autochthon of the Vuktyl oiland-gas-condensate field," Neftegaz. Geol. Teor. Prakt. 10 (3), 1-12 (2015). doi 10.17353/2070-5379/30_2015

21. G. A. Petrov, Yu. L. Ronkin, A. V. Maslov, I. A. Svyazhina, A. V. Rybalka, and O. P. Lepikhina, "Timing of the onset of collision in the Central and Northern Urals," Dokl. Earth Sci. 422, 1050-1055 (2008).

22. Yu. G. Pogrebitskii, Novaya Zemlya and Vaigach Island (VNIIOkeangeologiya, St. Petersburg, 2004) [in Russian].

23. L. M. Popova, A. M. Tyurin, V. M. Popov, et al., Seismic Surveys in the Eastern Side of the Fore-Uralian Foredeep and Frontal Folds of the Urals (Udmurtgeofizika, Izhevsk, 2013) [in Russian].

24. O. M. Prischepa, T. K. Bazhenova, and V. I. Bogatskii, "Petroleum systems of the Timan-Pechora sedimentary basin (including the offshore Pechora Sea)," Russ. Geol. Geophys. 52, 888-905 (2011).

25. O. M. Prishchepa, V. A. Zhitneykov, L. A. Orlova, and O. V. Chumakova, "Korotaikha depression, the new region of promising oil and gas resources in the TimanPechora Province," Geol., Geofiz. Razrab. Neft. Gaz. Mestorozhd., No. 5, 4-13 (2012).

26. O. M. Prishchepa, L. A. Orlova, and O. V. Chumakova, "Directions of geological surveys for oil and gas in the northeastern Timan-Pechora Province,” Neftegaz. Geol. Teor. Prakt. 3 (3), 1-22 (2008). http://www.ngtp.ru/ rub/4/40_2008.pdf.

27. V. N. Puchkov, Geology of the Urals and Fore-Uralian Region: Topical Problems of Stratigraphy, Tectonics, Geodynamics, and Metallogeny (DizainPoligrafServis, Ufa, 2010) [in Russian].

28. V. N. Puchkov, Paleogeodynamics of the Southern and Middle Urals (GILEM, Ufa, 2000) [in Russian].

29. V. N. Puchkov, "Formation of the Urals-Novaya Zemlya Foldbelt: A result of irregular oblique collision of the continents," Geotectonics 30, 400-409 (1996).

30. A. V. Ryazantsev, S. V. Dubinina, N. B. Kuznetsov, and A. A. Belova, "Ordovician lithotectonic complexes in allochthons of the Southern Urals," Geotectonics 42, 368-395 (2008).

31. A. V. Ryazantsev, A. A. Razumovskii, N. B. Kuznetsov, E. A. Kalinina, S. V. Dubinina, and V. A. Aristov, "Geodynamics nature of serpentinite mélanges in South Urals," Byull. Mosk. O-va. Ispyt. Prir., Otd. Geol. 82 (1), 32-47 (2007).

32. A. A. Smyslov, Geological Atlas of Russia. Geological Map of Russia and Adjacent Water Areas, Scale 1 : 10000000 , Ed. by R. I. Sokolov, B. G. Lopatin, and I. M. Gasheva (VSEGEI, St. Petersburg, 1995).

33. A. A. Soboleva, Volcanic Rocks and Associated Granitoids of the Near-Polar Urals (Ural. Otd. Ross. Akad. Nauk, Yekaterinburg, 2004) [in Russian].

34. A. A. Soboleva, A. F. Karchevskii, L. I. Efanova, N. B. Kuznetsov, M. Grove, I. D. Sobolev, and M. V. Maurin, "Evidence for Late Riphean granite formation in the Polar Urals," Dokl. Earth Sci. 442, 181187 (2012).

35. K. O. Sobornov, "Zones of wedge-shaped indenters: Structure and perspectives for oil and gas potential," Geol. Nefti Gaza, No. 8, 3-6 (1990).

36. K. O. Sobornov and A. S. Bushuev, "Kinematics of the junction zone between North Urals and Upper Pechora Basin," Geotektonika, No. 1, 39-51 (1992).

37. K. O. Sobornov and V. B. Rostovshchikov, "New directions of searching for oil and gas in the thrust belt of North Urals," Geol. Nefti Gaza, No. 6, 30-34 (1995).

38. N. I. Timonin and V. V. Yudin, "Paykhoyides as a special dislocation complex in earth's crust," Litosfera, No. 2, 24-37 (2002).

39. N. I. Timonin, V. V. Yudin, and A. A. Belyaev, Paleogeodynamics of Pay Khoy (Ural. Otd. Ross. Akad. Nauk, Yekaterinburg, 2004) [in Russian].

40. D. Brown, J. Alvarez-Marron, A. Perez-Estaun, Y. Gorozhanina, and V. Puchkov, "The structure of the south Urals foreland fold and thrust belt at the transition to the Precaspian Basin," J. Geol. Soc. (London, U. K.) 161, 813-822 (2004).

41. E. V. Khain, E. V. Bibikova, E. B. Salnikova, A. Kröner, A. S. Gibsher, A. N. Didenko, K. E. Degtyarev, and A. A. Fedotova, "The Palaeo-Asian ocean in the Neoproterozoic and early Paleozoic: New geochronologic 
data and paleotectonic reconstructions," Precambrian Res. 122, 329-358 (2003).

42. A. Kröner, V. Kovach, E. Rytsk, E. Belousova, E. Hegner, R. Armstrong, A. Dolgopolova, R. Seltmann, D. V. Alexeiev, K. E. Degtyarev, J. E. Hoffmann, J. Wong, M. Sun, K. Cai, T. Wang, et al., "Reassessment of continental growth during the accretionary history of the Central Asian Orogenic Belt," Gondwana Res. 25, 103-125 (2014).

43. L. B. Magoon and W. G. Dow, "The petroleum system," in The Petroleum System-from Source to Trap, Vol. 60 of $A A P G$ Mem., Ed. by L. B. Magoon and W. G. Dow (Tulsa, Okl., 1994), pp. 3-24.

44. A. V. Maslov, "Riphean and Vendian sedimentary sequences of the Timanides and Uralides, the eastern periphery of the East European Craton," in The Neoproterozoic Timanide Orogen of Eastern Baltica, Vol. 30 of Geol. Soc. London, Mem., Ed. by D. G. Gee and V. Pease (London, 2004), pp. 19-35. doi 10.1144/GSL. MEM.2004.030.01.03

45. A. V. Osipov, A. S. Monakova, M. V. Zakharchenko, and R. N. Mustaev, "Assessment of caprock fluid-resistive characteristics of Pre-Urals fore deep southern part,"
Geomodel 2015-17th Scientific-Practical Conference on Oil and Gas Geological Exploration and Development, 2015, pp. 649-653. doi 10.3997/2214-4609.201414018

46. O. V. Petrov, Yu. G. Leonov, and I. I. Pospelov, Tectonics of Northern, Central and Eastern Asia. Explanatory Note to the Tectonic map of Northern-Central-Eastern Asia and Adjacent Areas at Scale $1: 250$ 000, Ed. by O. V. Petrov, Yu. G. Leonov, T. Li, and O. Tomurtogoo (VSEGEI, St. Petersburg, 2014) [in Russian].

47. M. Z. Rachinsky and V. Yu. Kerimov, Fluid Dynamics of Oil and Gas Reservoirs (Wiley, Salem, Mass., 2015).

48. B. P. Wygrala, PhD Thesis (Univ. Cologne, Cologne, 1989).

49. IGEOSS software, Schlumberger. https://www.software.slb.com/products/igeoss. Accessed December 29, 2017.

50. PETROMOD software, Schlumberger. https://www. software.slb.com/products/petromod. Accessed December 29, 2017.

Reviewers: V.N. Puchkov, M.G. Leonov 